Vol. 10 (4): 667-670 (2020)

\title{
TECHNOLOGICAL QUALITIES OF LOCAL WHEATS FOR BREAD PRODUCTION
}

\author{
Ibrahim Hoxha ${ }^{1}$, Nexhdet Shala ${ }^{2 *}$, Arsim Elshani ${ }^{3}$, Gafur Xhabiri ${ }^{4}$ \\ 1,2*,3 University of "Haxhi Zeka", Faculty of Agribusiness, Peja-30000, Kosovo; \\ ${ }^{4}$ University of Tetova, Faculty of Food Technology and Nutrition, Tetova-1200, North Macedonia; \\ "Corresponding author Nexhdet Shala, e-mail:nexhdet.shala@unhz.eu;
}

Received August 2020; Accepted September 2020; Published October 2020;

DOI: https://doi.org/10.31407/ijees10.413

\begin{abstract}
Wheat is the most important agricultural crop in the world and in our country. It is the main source of energy, respectively daily calories and of some minerals and B complex group vitamins in human nutrition. Exactly in our country we have an annual production that satisfies the needs of about $57 \%$, and the import depends on its quality and yield. Therefore, this paper has the main object to study the physical, chemical and rheological qualities of wheat cultivated in different regions of Kosovo for bread production; this product which is still mostly consumed in our country. The results of the analysis show that the analysed grains have average physical quality which means that they can be stored and ground without any problem. From chemical qualities such as protein content, respectively gluten is ideal for bread production. Rheological analyses show that we are dealing with doughs with very good water absorption capacity of $59.67 \pm 1.364 \%$, as well as with the degree of softening, resistance, energy and maximum viscosity ideal for bread production.
\end{abstract}

Key words: gluten, physical qualities, rheological qualities, wheat. 